\section{Neuroimaging findings in post-traumatic stress}

\section{disorder}

\author{
Systematic review
}

ALASTAIR M. HULL

\begin{abstract}
Background Findings from neuroimaging studies complement our understanding of the wide-ranging neurobiological changes in trauma survivors who develop post-traumatic stress disorder (PTSD).
\end{abstract}

Aims To determine whether neuroimaging studies had identified structural and functional changes specific to PTSD.

Method A review of all functional and structural neuroimaging studies of subjects with PTSD was carried out. Studies were identified using general medical and specific traumatic stress databases and paper searches of current contents and other secondary sources.

Results The most replicated structural finding is hippocampal volume reduction, which may limit the proper evaluation and categorisation of experience. Replicated localised functional changes include increased activation of the amygdala after symptom provocation (which may reflect its role in emotional memory) and decreased activity of Broca's area at the same time (which may explain the difficulty patients have in labelling their experiences).

\section{Conclusions Evidence from} neuroimaging studies has suggested areas of the brain that may be damaged by psychological trauma. The clinical implications of these neuroimaging findings need to be investigated further because they challenge traditional therapeutic approaches.

Declaration of interest None.
Psychological reactions to traumatic events such as post-traumatic stress disorder (PTSD) are common and clinically important, with PTSD shown to have a lifetime prevalence in community samples of between $1.3 \%$ (Helzer et al, 1987) and 9\% (Breslau et al, 1991). Research has confirmed the complex aetiology, epidemiology and symptomatology of PTSD and demonstrated a wide range of neurobiological changes (Friedman, 1997). Neuroimaging techniques provide opportunities to investigate structural and functional brain abnormalities, with the challenge then to integrate ever more complex neurobiological models across many neurochemical systems and structures into a cohesive understanding of PTSD.

This review examines structural and functional studies of the brain and also studies combining both modalities. Symptom and non-symptom provocation paradigms are examined in relation to functional studies, with case reports reviewed separately. Finally, the implications of these findings are discussed.

\section{METHOD}

Neuroimaging studies of subjects with PTSD were identified using literature searches of the Medline, Psychlit, Embase and Published International Literature on Traumatic Stress (PILOTS) databases, current contents, recent journal issues, reference lists and secondary sources (e.g. book chapters). A total of 30 published reports were located: 12 reports of brain structure in PTSD and 18 reports of brain function in PTSD (with two of these studies combining the imaging modalities). All English language articles published by August 2001 were included in this review.

\section{RESULTS}

Studies of brain structure in patients with PTSD

Computed tomography studies were first to suggest brain abnormalities in PTSD (Table 1) and there have been eight reports on magnetic resonance imaging (MRI) studies in subjects with PTSD (Table 2).

A number of studies have now demonstrated the involvement of the hippocampus in chronic PTSD. Two studies have examined the hippocampus without finding volumetric changes. The first study demonstrated the absence of hippocampal atrophy prior to the onset of PTSD (Bonne et al, 2001). Further, after single-event trauma, hippocampal abnormalities did not occur within 6 months. The second study (De Bellis et al, 1999) demonstrated smaller cerebral volumes and corpus callosum measures but no hippocampal changes in a group of maltreated children.

Possible reasons for the differences in the extent of volume reduction may be the study design (thickness of slices or whether or not the whole brain volume was calculated), the control group utilised, comorbid substance misuse, treatment effects or neurodevelopmental plasticity. In the main, researchers have performed comparative analyses to minimise the effect of other psychiatric disorders, including alcohol and substance misuse.

Sapolsky (1992) has described the sensitivity of hippocampal formation to severe, chronic traumatic stress and perhaps also to elevated glucocorticoids and/or excitatory amino acids, yet many other disorders such as bipolar disorder, schizophrenia, alcohol misuse and dementia are also associated with hippocampal atrophy (McEwen, 1997). Glucocorticoid-induced atrophy would appear to require prolonged or repeated bursts of glucocorticoid excess. However, basal glucocorticoid levels have been shown to be lower than normal in PTSD, perhaps due to enhanced adrenocortical sensitivity to feedback regulation (Yehuda et al, 1991, 1993).

The lateralisation of hippocampal damage has varied, with one possible explanation being changing vulnerability of the hippocampus to stress-induced damage at different developmental stages. The possibility that small hippocampi represent a predisposition to PTSD is not supported by the one study to examine acute PTSD (Bonne et al, 2001) because no change in volume was present acutely or within the 
Table I Computed tomography studies of patients with post-traumatic stress disorder (PTSD)

\begin{tabular}{|c|c|c|c|c|}
\hline Author & Subjects & $\begin{array}{l}\text { Control/comparison } \\
\text { groups }\end{array}$ & $\begin{array}{l}\text { Diagnostic } \\
\text { criteria (method) }\end{array}$ & Results \\
\hline Silverman et al, 1989 & $\begin{array}{l}14 \text { exposed to neurotoxin (pentaborane); } \\
7 \text { with PTSD (7M; 7F) }\end{array}$ & None & $\begin{array}{l}\text { DSM-III (Diagnostic } \\
\text { Interview Schedule) }\end{array}$ & $\begin{array}{l}\text { Abnormal VBRs at I-3 and } 18 \text { months } \\
\text { post-exposure; no association with PTSD } \\
\text { or other diagnosis; abnormal VBRs may } \\
\text { be due to neurotoxin }\end{array}$ \\
\hline Peters et al, 1990 & 10 former prisoners of war (all M) & None & Not specified & $\begin{array}{l}\text { Increased VBR and sulcal widening } \\
\text { associated with sleep disturbances }\end{array}$ \\
\hline
\end{tabular}

VBR, ventricular brain ratio; $M$, male; $F$, female.

Table 2 Magnetic resonance imaging studies of patients with post-traumatic stress disorder (PTSD)

\begin{tabular}{|c|c|c|c|c|}
\hline Author (method) & Subjects & $\begin{array}{l}\text { Control/comparison } \\
\text { groups }\end{array}$ & $\begin{array}{l}\text { Diagnostic criteria } \\
\text { (method) }\end{array}$ & Results \\
\hline Myslobodsky et al, 1995 & $\begin{array}{l}\text { I0 CR-PTSD } \\
\text { (gender not specified) }\end{array}$ & 10 matched controls & $\begin{array}{l}\text { DSM-III (PTSD } \\
\text { symptom checklist) }\end{array}$ & $\begin{array}{l}\text { Increased incidence of cavum septum pellucidum } \\
\text { (a neurodevelopmental abnormality) }\end{array}$ \\
\hline Bremner et al, 1995 & 26 CR-PTSD (all M) & $\begin{array}{l}22 \text { non-CE matched } \\
\text { controls (all M) }\end{array}$ & $\begin{array}{l}\text { DSM-III-R } \\
\text { (Mississippi Scale } \\
\text { for CR-PTSD) }\end{array}$ & $\begin{array}{l}\text { Reduced (R)HC volume, correlates with memory } \\
\text { impairment (verbal memory component of } \\
\text { Wechsler Memory Scale); no correlation with } \\
\text { PTSD symptom severity, dissociation or CE } \\
\text { severity }\end{array}$ \\
\hline Gurvits et al, 1996 & 7 CR-PTSD (all M) & $\begin{array}{l}7 \text { CE non-PTSD controls } \\
\text { (all M); } 8 \text { non-CE controls } \\
\text { (gender not specified) }\end{array}$ & DSM-III-R (CAPS) & $\begin{array}{l}\text { Bilateral reduction in } \mathrm{HC} \text { volume with } \\
\text { statistically significant correlation between } \\
\text { (L) } \mathrm{HC} \text { volume and } \mathrm{CE}\end{array}$ \\
\hline Bremner et al, 1997a & $\begin{array}{l}\text { I7 survivors of CSA and/or } \\
\text { physical abuse (I2M; } 5 F)\end{array}$ & $\begin{array}{l}\text { I7 case-matched controls } \\
(I 2 \mathrm{M} ; 5 \mathrm{~F})\end{array}$ & $\begin{array}{l}\text { DSM-III-R (Early } \\
\text { Trauma Inventory) }\end{array}$ & $\begin{array}{l}\text { Reduced }(\mathrm{L}) \mathrm{HC} \text { volume correlates with abuse } \\
\text { duration; trend for larger amygdala in PTSD; } \\
\text { reduction in }(\mathrm{R}) \mathrm{HC} \text { not statistically significant }\end{array}$ \\
\hline Stein et al, 1997 & 21 survivors of CSA (all F) & 21 non-CSA (all F) & DSM-IV (CAPS) & $\begin{array}{l}\text { Reduced (L)HC volume correlates with } \\
\text { dissociative symptoms and to lesser extent PTSD } \\
\text { symptoms }\end{array}$ \\
\hline $\begin{array}{l}\text { Canive et al, } 1997 \\
\text { (FLAIR sequence) }\end{array}$ & 42 CR-PTSD (all M) & 20 controls (all M) & $\begin{array}{l}\text { DSM-III-R (CAPS } \\
\text { and Mississippi } \\
\text { Scale for CR-PTSD) }\end{array}$ & Focal WMLs in 8 CR-PTSD subjects \\
\hline De Bellis et al, 1999 & $\begin{array}{l}44 \text { maltreated children with } \\
\text { PTSD (25M; I9F) }\end{array}$ & $\begin{array}{l}61 \text { case-matched } \\
\text { non-abused controls } \\
(36 \mathrm{M} ; 25 \mathrm{~F})\end{array}$ & $\begin{array}{l}\text { DSM-III and DSM-IV } \\
\text { (non-standardised } \\
\text { measures) }\end{array}$ & $\begin{array}{l}\text { No HC changes; smaller cerebral volumes and } \\
\text { total corpus callosum measures correlate with } \\
\text { PTSD; cerebral volume correlates with age of } \\
\text { onset of trauma and negatively with duration of } \\
\text { abuse }\end{array}$ \\
\hline Bonne et al, $200 \mathrm{I}$ & $\begin{array}{l}10 \text { miscellaneous trauma } \\
(3 \mathrm{M}: 7 \mathrm{~F})\end{array}$ & $\begin{array}{l}27 \text { TE controls } \\
\text { (I5M: I2F) }\end{array}$ & $\begin{array}{l}\text { DSM-IV (CAPS at } \\
6 \text { months) }\end{array}$ & $\begin{array}{l}\text { No reduction in } \mathrm{HC} \text { volume at I week or } \\
6 \text { months post-trauma }\end{array}$ \\
\hline
\end{tabular}

CR, combat-related; CE, combat-exposed; TE, trauma-exposed; HC, hippocampus; CSA, child sexual abuse; M, male; F, female; (R), right; (L), left; FLAIR, fluid attenuated inversion recovery imaging; CAPS, Clinician Administered PTSD Scale; WML, white matter lesion.

first 6 months. Further, Bremner et al (1995) demonstrated no volume difference between early-onset (before age 8 years) and late-onset (age 8 years or later) abuse.

Canive et al (1997) have uniquely demonstrated focal white matter lesions (WMLs) in eight subjects within a sample of 42 male combat-exposed subjects. Most of the WMLs were identified using the fluid attenuated inversion recovery (FLAIR) imaging sequence, which is not employed in typical MRI studies. The FLAIR sequence causes suppression of the cerebrospinal fluid signal with WML remaining bright, and the absence of the FLAIR imaging sequence may explain why other studies have not replicated this finding.

\section{Studies using proton magnetic resonance spectroscopy in patients with PTSD}

Proton magnetic resonance spectroscopy (MRS) can provide information about alterations in $\mathrm{N}$-acetyl aspartate (NAA) and choline-containing compounds in the human brain without the radiation 
exposure of positron emission tomography (PET) on single photon emission computed tomography (SPECT) but with lower sensitivity. Two studies have utilised this technique (Table 3) to measure NAA in subjects with PTSD. Schuff et al (1997) utilised both MRI and proton MRS to measure hippocampal volume and changes in NAA. An $18 \%$ reduction in right hippocampal NAA compared with a $6 \%$ reduction in right hippocampal volume suggests that NAA is a more sensitive measure of neuronal loss than volume changes. Although this study does not answer whether the NAA changes were preexisting or a consequence of trauma rather than PTSD per se, the second study (Freeman et al, 1998) suggests that it correlated with PTSD. Decreased NAA has been demonstrated in other disorders, such as early-onset schizophrenia (Bertolino et al, 1996), temporal lobe epilepsy (Ende et al, 1997) and Alzheimer's disease (MacKay et al, 1996).

\section{Studies of brain function in patients with PTSD}

Most functional brain imaging studies in PTSD have used either PET or SPECT, which involve the detection of radiationemitting radioisotopes to measure regional cerebral metabolism or blood flow. Functional MRI determines regional brain activation by detecting changes in blood oxygenation level and has a better spatial resolution than PET or SPECT.

The majority of studies employed a symptom provocation paradigm because measuring brain function at rest poses the problem of controlling the range of possible mental states. Studies have concentrated upon traumatic memory as a central component in PTSD because the presence of intrusive symptoms compellingly points to PTSD as the diagnosis. The one study to employ a non-symptom provocation paradigm (Lucey et al, 1997) used SPECT to study three groups with anxiety-related disorders: PTSD, obsessive-compulsive disorder (OCD) and agoraphobia with panic disorder (see Table 5). One study utilised a pharmacological challenge and is discussed separately below (Bremner et al, 1997b).

\section{Pharmacological challenge study}

Bremner et al (1997b) administered the $\alpha_{2}$-antagonist yohimbine in a pharmacological challenge symptom provocation paradigm (Table 4). Yohimbine has been shown to provoke an exaggerated behavioural and biochemical responsiveness in subjects with PTSD (Southwick et al, 1993) and panic disorder (Charney et al, $1987 a$ ) but not in patients with other mental disorders (Charney et al, 1987b; Glazer et al, 1987; Rasmussen et al, 1987; Heninger et al, 1988). Bremner et al demonstrated that yohimbine administration correlated with increased anxiety symptoms in patients with PTSD but not in controls. Patients with yohimbineinduced panic attack (approximately $60 \%$ ) had significantly reduced hippocampal and neocortical metabolism, suggesting enhanced noradrenaline release in subjects with PTSD after yohimbine administration.

\section{Symptom provocation studies using PET}

The majority of PET studies (six reports) provoked intrusive symptoms by using personalised trauma scripts or trauma-related sounds or pictures (Table 4), and one group examined changes during the performance of cognitive tasks (Semple et al, 1993, 1996, 2000).

\section{Symptom provocation studies using SPECT}

Only three SPECT studies have examined subjects with PTSD after symptom provocation (Table 5). Liberzon et al have conducted a SPECT study of subjects with combat-related PTSD and reported key findings in two papers (Liberzon et al, 1999; Zubieta et al, 1999) and one case report (Liberzon et al, 1996/97). They report separately on a specific analysis of the activity of the medial prefrontal cortex, which is thought to modulate the fear response (Zubieta et al, 1999). An increased regional cerebral blood flow (rCBF) was found in the medial prefrontal cortex in subjects with PTSD during provocation, although no statistically significant association was found with peripheral measures. The different findings may reflect the fact that the subjects were from the same cohort but the region-of-interest analysis was derived from a different cohort of normal controls. The anatomical region sampled for the region-of-interest analysis was more rostral than the anterior cingulate

Table 3 Functional magnetic resonance imaging (MRI) and magnetic resonance spectroscopy (MRS) studies in patients with post-traumatic stress disorder (PTSD)

\begin{tabular}{|c|c|c|c|c|c|}
\hline Author (tracer used) & Subjects & Controls/comparators & $\begin{array}{l}\text { Design/method of } \\
\text { provocation }\end{array}$ & $\begin{array}{l}\text { Diagnostic } \\
\text { criteria (method) }\end{array}$ & Results \\
\hline $\begin{array}{l}\text { Schuff et al, } 1997 \\
\text { (proton MRS and MRI) }\end{array}$ & $\begin{array}{l}7 \text { CR-PTSD ( } 6 \text { M; I F); } 5 \text { of } \\
\text { the } 7 \text { completed both scans }\end{array}$ & $\begin{array}{l}7 \text { non-veteran controls } \\
\text { (gender not specified) }\end{array}$ & Measurement of NAA & Not specified & $\begin{array}{l}\text { Reduced (R)HC NAA } \\
\text { (greater than reduced } \\
\text { (R)HC volume) }\end{array}$ \\
\hline $\begin{array}{l}\text { Freeman et al, } 1998 \\
\text { (proton MRS) }\end{array}$ & 2I CR-PTSD & 8 CE-PTSD & $\begin{array}{l}\text { Measurement of NAA/ } \\
\text { creatine ratio }\end{array}$ & $\begin{array}{l}\text { DSM-IV (CAPS } \\
\text { and SCID) }\end{array}$ & $\begin{array}{l}\text { Decreased NAA/creatine } \\
\text { ratios in the medial tempor- } \\
\text { al lobes bilaterally, with (R) } \\
\text { significantly lower than }(\mathrm{L})\end{array}$ \\
\hline $\begin{array}{l}\text { Rauch et al, } 2000 \\
\text { (functional MRI) }\end{array}$ & 8 CR-PTSD (all M) & 8 CE non-PTSD (all M) & Masked face paradigm & DSM-IV (CAPS) & $\begin{array}{l}\text { Exaggerated automatic } \\
\text { amygdalar response to } \\
\text { threat-related stimuli }\end{array}$ \\
\hline
\end{tabular}

CR, combat-related; CE, combat-exposed; M, male; F, female; (R), right; (L), left; SCID, Structured Clinical Interview for DSM-IV; CAPS, Clinician Administered PTSD Scale; NAA $\mathrm{N}$-acetyl aspartate; $\mathrm{HC}$, hippocampus. 
Table 4 Positron emission tomography (PET) studies of patients with post-traumatic stress disorder (PTSD)

\begin{tabular}{|c|c|c|c|c|c|}
\hline Author (tracer used) & Subjects & $\begin{array}{l}\text { Controls/ } \\
\text { comparison groups }\end{array}$ & $\begin{array}{l}\text { Design/method of } \\
\text { provocation }\end{array}$ & $\begin{array}{l}\text { Diagnostic } \\
\text { criteria (method) }\end{array}$ & Results \\
\hline $\begin{array}{l}\text { Semple et al, } 1993 \\
\left({ }^{15} \mathrm{O}-\mathrm{H}_{2} \mathrm{O}\right)\end{array}$ & $\begin{array}{l}6 \text { CR-PTSD } \\
\text { (all M; } 5 \text { with SA) }\end{array}$ & $\begin{array}{l}7 \text { controls } \\
\text { (all M with SM) }\end{array}$ & $\begin{array}{l}\text { Auditory continuous } \\
\text { performance task, } \\
\text { word generation task }\end{array}$ & Not specified & $\begin{array}{l}\text { Increased rCBF in orbitofrontal } \\
\text { cortex }\end{array}$ \\
\hline $\begin{array}{l}\text { Rauch et al, } 1996 \\
\left({ }^{15} \mathrm{O}-\mathrm{CO}_{2}\right)\end{array}$ & $\begin{array}{l}8 \text { miscellaneous } \\
\text { trauma 'physiological } \\
\text { responders' (2M; 6F) }\end{array}$ & $\begin{array}{l}\text { No controls (within- } \\
\text { subject design) }\end{array}$ & $\begin{array}{l}\text { Personal traumatic } \\
\text { script }\end{array}$ & DSM-III-R (SCID) & $\begin{array}{l}\text { Increased rCBF in }(R) \text { limbic, } \\
\text { paralimbic and }(R) \text { secondary visual } \\
\text { areas; decreased rCBF in Broca's area } \\
((\mathrm{L}) \text { inferior frontal cortex) and }(\mathrm{L}) \\
\text { middle temporal cortex }\end{array}$ \\
\hline $\begin{array}{l}\text { Semple et al, } 1996 \\
\left({ }^{15} \mathrm{O}-\mathrm{H}_{2} \mathrm{O}\right)\end{array}$ & $\begin{array}{l}8 \text { CR-PTSD } \\
\text { (all M with CA) }\end{array}$ & $\begin{array}{l}8 \text { controls } \\
\text { (all } M \text { with CA) }\end{array}$ & $\begin{array}{l}\text { Auditory attentional } \\
\text { task }\end{array}$ & $\begin{array}{l}\text { DSM-III-R } \\
\text { (Mississippi Scale } \\
\text { for CR-PTSD) }\end{array}$ & $\begin{array}{l}\text { Decreased parietal rCBF during } \\
\text { attentional tasks }\end{array}$ \\
\hline $\begin{array}{l}\text { Bremner et al, } \\
1997 b \\
\left({ }^{18} \mathrm{~F}-\mathrm{FDG} \text { and } \mathrm{MRI}\right)\end{array}$ & $\begin{array}{l}\text { I0 CR-PTSD } \\
\text { (all M) }\end{array}$ & $\begin{array}{l}\text { I0 non-CE controls } \\
\text { (all M) }\end{array}$ & $\begin{array}{l}\text { Yohimbine } \\
\text { administration }\end{array}$ & $\begin{array}{l}\text { DSM-III-R } \\
\text { (Mississippi Scale } \\
\text { for CR-PTSD) }\end{array}$ & $\begin{array}{l}\text { Increased noradrenaline release in } \\
\text { subjects with PTSD after yohimbine; } \\
\text { correlates with decreased metabolism } \\
\text { in PTSD in hippocampus and neocor- } \\
\text { tical regions and increased metabo- } \\
\text { lism in controls }\end{array}$ \\
\hline $\begin{array}{l}\text { Shin et } a l, 1997 a, b \\
\left({ }^{15} \mathrm{O}-\mathrm{CO}_{2}\right)\end{array}$ & $\begin{array}{l}7 \text { CR-PTSD } \\
\text { (all M) }\end{array}$ & $\begin{array}{l}7 \text { CE non-PTSD } \\
\text { controls (all M) } \\
\text { (significant age } \\
\text { difference between } \\
\text { groups) }\end{array}$ & $\begin{array}{l}\text { CR pictures (viewed } \\
\text { and personally } \\
\text { generated mental } \\
\text { images) }\end{array}$ & DSM-III-R (CAPS) & $\begin{array}{l}\text { Increased rCBF in anterior cingulate } \\
\text { gyrus and }(\mathrm{R}) \text { amygdala during } \\
\text { mental imagery; decreased rCBF in } \\
\text { Broca's area when viewing combat } \\
\text { pictures }\end{array}$ \\
\hline $\begin{array}{l}\text { Rauch et al, } 1997 \\
\left({ }^{15} \mathrm{O}-\mathrm{CO}_{2}\right)\end{array}$ & $\begin{array}{l}8 \text { miscellaneous PTSD } \\
(2 \mathrm{M} ; 6 \mathrm{~F})\end{array}$ & $\begin{array}{l}7 \text { simple phobia (IM; } \\
6 \mathrm{~F}) ; 8 \text { OCD (5M; 3F); } \\
\text { no controls }\end{array}$ & Personal trauma script & DSM-III-R (SCID) & $\begin{array}{l}\text { Increased rCBF in paralimbic belt }((R) \\
\text { frontal and subcortical nuclei) in } \\
\text { anxiety disorders }\end{array}$ \\
\hline $\begin{array}{l}\text { Bremner et al, } 1999 a \\
\left({ }^{15} \mathrm{O}-\mathrm{H}_{2} \mathrm{O}\right)\end{array}$ & $\begin{array}{l}\text { I0 CR-PTSD } \\
\text { (all M) }\end{array}$ & $\begin{array}{l}\text { I0 CE non-PTSD } \\
\text { (all M) }\end{array}$ & $\begin{array}{l}\text { Sound and visual } \\
\text { images of } C R \text { trauma }\end{array}$ & DSM-IV (SCID) & $\begin{array}{l}\text { Decreased rCBF in medial prefrontal } \\
\text { cortex; increased rCBF in anterior } \\
\text { cingulate in non-PTSD subjects; no } \\
\text { amygdalar activation }\end{array}$ \\
\hline $\begin{array}{l}\text { Bremner et al, } 1999 b \\
\left({ }^{15} \mathrm{O}-\mathrm{H}_{2} \mathrm{O}\right)\end{array}$ & $\begin{array}{l}\text { I0 CSA-related PTSD } \\
\text { (all F) }\end{array}$ & $\begin{array}{l}\text { I2 CSA non-PTSD } \\
\text { (all F) }\end{array}$ & Personal trauma script & DSM-IV (SCID) & $\begin{array}{l}\text { Increased rCBF of posterior } \\
\text { cingulate, motor cortex and } \\
\text { prefrontal cortex; decreased rCBF in } \\
\text { visual association cortex, inferior } \\
\text { temporal gyrus, anterior cingulate, } \\
\text { (R) hippocampus and supramarginal } \\
\text { gyrus; no amygdalar activation }\end{array}$ \\
\hline $\begin{array}{l}\text { Shin et al, } 1999 \\
\left({ }^{15} \mathrm{O}-\mathrm{CO}_{2}\right)\end{array}$ & $\begin{array}{l}8 \text { CSA-related PTSD } \\
\text { (all F) }\end{array}$ & $\begin{array}{l}8 \text { CSA non-PTSD } \\
\text { (all F) }\end{array}$ & $\begin{array}{l}\text { Personal trauma } \\
\text { scripts and trauma } \\
\text { imagery }\end{array}$ & DSM-III-R (CAPS) & $\begin{array}{l}\text { Increased rCBF in orbitofrontal } \\
\text { cortex and anterior temporal poles; } \\
\text { decreased } r C B F \text { in bilateral anterior } \\
\text { frontal regions and (L) inferior } \\
\text { frontal gyrus; no amygdalar } \\
\text { activation }\end{array}$ \\
\hline $\begin{array}{l}\text { Semple et al, } 2000 \\
\left({ }^{15} \mathrm{O} \text {-butanol) }\right.\end{array}$ & $\begin{array}{l}7 \text { CR-PTSD (all M) } \\
\text { with CA }\end{array}$ & $\begin{array}{l}6 \text { normal controls } \\
\text { (all M) }\end{array}$ & $\begin{array}{l}\text { Auditory attentional } \\
\text { task }\end{array}$ & Not specified & $\begin{array}{l}\text { Increased rCBF in }(\mathrm{R}) \text { amygdala and } \\
(\mathrm{L}) \text { parahippocampal gyrus during } \\
\text { performance tasks; decreased rCBF in } \\
\text { frontal cortex at rest and during at- } \\
\text { tentional tasks }\end{array}$ \\
\hline
\end{tabular}

CR, combat-related; CE, combat-exposed; SM, substance misuse; CA, cocaine and alcohol misuse; CSA, child sexual abuse; $M$, male; F, female; (R), right; (L), left; ${ }^{18} \mathrm{~F}-\mathrm{FDG}$, ${ }^{18} \mathrm{~F}$-fluorodeoxyglucose; ${ }^{15} \mathrm{O}-\mathrm{CO}_{2},{ }^{15} \mathrm{O}$-labelled $\mathrm{CO}_{2} ;{ }^{15} \mathrm{O}-\mathrm{H}_{2} \mathrm{O},{ }^{15} \mathrm{O}$-labelled $\mathrm{H}_{2} \mathrm{O}$; ${ }^{15} \mathrm{O}$-butanol, ${ }^{15} \mathrm{O}$-labelled butanol; SCID, Structured Clinical Interview for DSM-IV; MRI, magnetic resonance imaging; CAPS, Clinician Administered PTSD Scale; rCBF, regional cerebral blood flow; OCD, obsessive-compulsive disorder. 
Table 5 Single photon emission computed tomography (SPECT) studies in patients with post-traumatic stress disorder (PTSD)

\begin{tabular}{|c|c|c|c|c|c|}
\hline $\begin{array}{l}\text { Author (tracer } \\
\text { used) }\end{array}$ & Subjects & $\begin{array}{l}\text { Controls/ } \\
\text { comparison groups }\end{array}$ & $\begin{array}{l}\text { Design/method } \\
\text { of provocation }\end{array}$ & $\begin{array}{l}\text { Diagnostic } \\
\text { criteria (method) }\end{array}$ & Results \\
\hline $\begin{array}{l}\text { Lucey et al, } 1997 \\
\text { (99mTcHMPAO) }\end{array}$ & $\begin{array}{l}\text { I6 PTSD (I4M; 2F) } \\
\text { (miscellaneous trauma) }\end{array}$ & $\begin{array}{l}\text { I5 OCD (8M; 7F); I5 } \\
\text { agoraphobia with panic } \\
\text { (8M; 7F); I5 controls } \\
\text { (8M; 7F) }\end{array}$ & $\begin{array}{l}\text { Non-symptom } \\
\text { provocation }\end{array}$ & $\begin{array}{l}\text { DSM-III-R } \\
\text { (Impact of } \\
\text { Event Scale) }\end{array}$ & $\begin{array}{l}\text { Reduced rCBF in caudate and superior } \\
\text { frontal cortex in PTSD and OCD; reduced } \\
\text { caudate rCBF correlates with depression } \\
\text { and PTSD severity }\end{array}$ \\
\hline 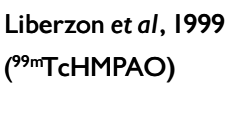 & I4 CR-PTSD (all M) & $\begin{array}{l}\text { II CE non-PTSD (all M); } \\
\text { I4 controls (all M) }\end{array}$ & $\begin{array}{l}\text { Audiotape of } \\
\text { combat sounds }\end{array}$ & $\begin{array}{l}\text { DSM-III-R } \\
\text { (SCID) }\end{array}$ & $\begin{array}{l}\text { Activation of }(\mathrm{L}) \text { amygdala in PTSD; } \\
\text { activation of anterior cingulate and medial } \\
\text { prefrontal cortex in all three groups }\end{array}$ \\
\hline $\begin{array}{l}\text { Zubieta et al, } 1999 \\
\text { (99mTcHMPAO) }\end{array}$ & I2 CR-PTSD (all M) & $\begin{array}{l}\text { II CE non-PTSD (all M); } \\
\text { I } 2 \text { controls (all M) }\end{array}$ & $\begin{array}{l}\text { Audiotape of } \\
\text { combat sounds }\end{array}$ & $\begin{array}{l}\text { DSM-III-R } \\
\text { (SCID) }\end{array}$ & $\begin{array}{l}\text { Activation of medial prefrontal cortex in } \\
\text { PTSD only }\end{array}$ \\
\hline $\begin{array}{l}\text { Bremner et al, } 2000 \\
\text { ('23|-iomazenil) }\end{array}$ & I3 CR-PTSD (all M) & $\begin{array}{l}\text { I3 case-matched } \\
\text { controls (all M) }\end{array}$ & $\begin{array}{l}\text { Measurement of } \\
\text { benzodiazepine } \\
\text { receptor binding }\end{array}$ & DSM-IV (SCID) & $\begin{array}{l}\text { PTSD subjects had } 41 \% \text { lower distribution } \\
\text { volumes in the prefrontal cortex (i.e. } \\
\text { lower benzodiazepine receptor binding) }\end{array}$ \\
\hline
\end{tabular}

OCD, obsessive-compulsive disorder; rCBF, regional cerebral blood flow; CR, combat-related; CE, combat-exposed; M, male; F, female; (R), right; (L), left; ${ }^{99 m T c H M P A O, ~ 99 m-~}$ technetium-d,I-hexamethylpropyleneamine oxide; SCID, Structured Clinical Interview for DSM-IV.

region examined by Liberzon et al (1999).

\section{Functional MRI studies}

Rauch et al (2000) conducted a functional MRI study applying a validated method for measuring automatic amygdala responses to general threat-related stimuli using a masked face paradigm (Whalen et al, 1998b). The magnitude of amygdala response distinguished subjects with PTSD from those without PTSD with $75 \%$ sensitivity and $100 \%$ specificity (Table 3).

\section{Case reports involving functional neuroimaging}

Levin et al (1999) report on one subject from an ongoing SPECT study utilising the same provocation paradigm as Rauch et al (1996). Subjects were scanned before and after successful treatment for PTSD. After treatment there were two areas of increased activity: the anterior cingulate cortex and the left frontal lobe. The treatment was eye movement desensitisation and reprocessing (EMDR; Shapiro, 1996) but the subject of this report was also on a selective serotonin reuptake inhibitor throughout the study. The authors state that these changes were consistent with summed data from four out of six subjects in their ongoing study.

Profound memory deficits were demonstrated in a case report of a man after a second traumatic event triggering memories of a fatal accident he witnessed as a child. A PET scan revealed hypoperfusion in memory-sensitive regions such as the hippocampal formation and temporal lobe (Markowitsch et al, 1998). Liberzon et al (1996/97) report one patient who experienced a flashback after provocation while being scanned. There was greater uptake in subcortical regions, especially the thalamus, in comparison with cortical regions.

\section{Summary of functional findings}

Many of the functional neuroimaging studies have suggested abnormalities of limbic and paralimbic areas during symptom provocation and cognitive activation studies. This supports the suggested role of these areas in mediating emotional arousal in normal anxiety (Benkelfat et al, 1996), across a range of disorders (Rauch et al, 1995) and in trauma-exposed non-PTSD groups. These changes are therefore not specific to PTSD. Hyperperfusion of limbic and paralimbic areas may be a result of stress-induced long-term potentiation of the monosynaptic $\mathrm{N}$-methyl-D-aspartate (NMDA)-mediated pathway between the amygdala and the periacqueductal grey (Davidson \& Sutton, 1995; Adamec, 1997). The NMDA receptors are thought to be activated to produce long-term memories of events when sufficient glutamate is released as a result of the stress (Glue $e t$ al, 1993).

Amygdalar activation may be detected more easily during the processing of fearrelated stimuli (Breiter et al, 1996; Morris et al, 1996; Whalen et al, 1998a). Inconsistent findings of amygdala activation may reflect the nature of the trauma, and the greater emotional responsiveness to personal narratives of traumatic events (Rauch et al, 1996) rather than to generalised trauma-related pictures and images (Shin et al, 1997a,b) or to generalised combat sounds (Bremner et al, 1999a). For example, Shin et al (1997b) found increased activation of the amygdala in PTSD only during combat imagery, despite both the imagery and combat perception conditions being rated as of equal significance and causing equal arousal. In addition, the failure to demonstrate amygdalar activation may be due to its involvement in encoding an event's emotional significance but not in the recall of the event per se (Cahill et al, 1996).

The role of the amygdala was investigated in subjects with probable Alzheimer's disease who experienced the 1995 earthquake in Kobe, Japan (Ikeda et al, 1998; Mori et al, 1999; Kazui et al, 2000). Memories of the earthquake were examined as an index of emotional memory. Subjects remembered their personal experience rather than the context of the earthquake, and emotional memory correlated with normalised amygdalar volume (via MRI) irrespective of generalised brain atrophy and cognitive impairments.

Increased automatic amygdalar responsiveness to stimuli (cognitive activation or masked face paradigm) has been shown to be accompanied by decreased activity of the prefrontal cortex, which has a role in 
the encoding and retrieval of verbal memories. Lower benzodiazepine receptor binding in the prefrontal cortex might mean that PTSD causes a down-regulation of benzodiazepine receptor binding or that pre-trauma low levels of benzodiazepine receptor binding in the prefrontal cortex might increase the risk of developing PTSD after traumatic events (Bremner et al, 2000).

Although needing replication, the study by Levin et al (1999) suggests that successful treatment may not only reduce amygdala activity but also may involve activation of structures implicated in the modulation of fight/flight reactions to perceived threat, and perhaps the differentiation of real from imagined threat. Increased perfusion of the thalamus during a flashback (Liberzon et al, 1996/97) supports its suggested role in the generation of dissociative symptoms in PTSD (Krystal et al, 1995).

The absence of increased anterior cingulate activation over comparison groups may be associated with the inability of people with PTSD to extinguish fear. It is thought to play a major role in the assignment of motivational significance and is associated with non-specific anxiety states being activated in procaine-induced fear (Ketter et al, 1996), imagery of aversive stimuli (Kosslyn et al, 1996) and healthy individuals recollecting sad events (Whalen et al, 1998a). The increased activation of the posterior cingulate (Bremner et al, 1999b) may relate to its suggested role in the emotional processing of distressing material (Fischer et al, 1996).

A replicated finding has been the deactivation of Broca's area, the area of the brain thought to be responsible for applying semantic representations to personal experience to allow its communication or description (Rauch et al, 1996; Shin et al, 1997b). This would appear to be consistent with subjects with PTSD having difficulty in cognitively restructuring their traumatic experience.

The modality of re-experiencing phenomena will have a bearing on regional brain activation. The mental imagery in the study by Rauch et al (1996) was predominantly visual, causing increased rCBF in the secondary visual cortex, a finding not found by Shin et al $(1997 a, b, 1999)$ because the re-experiencing phenomena in their study were predominantly tactile. These findings serve to illustrate that different types of trauma cause different emotional reactions; trauma memories are not uniform and activation of brain regions will vary. Further, hypoperfusion of the left inferior frontal gyrus in PTSD (Shin et al 1997a,b, 1999) may reflect the nature of intrusive thoughts because the frontal regions are implicated in effortful recall (Schacter et al, 1996), whereas intrusive phenomena are effortless and may therefore lead to hypoperfusion.

\section{DISCUSSION}

Neuroimaging is a powerful method to examine the links among structural and functional brain changes, psychopathology and findings from other neurobiological research in traumatised individuals. However, neuroimaging in PTSD is only just emerging from its infancy, with only 30 published reports as of August 2001. Results are far from uniform but the degree of consensus at this early stage is encouraging. Research in the trauma field is fraught with difficulties; one inherent difficulty in all trauma research is the choice of population to be studied. Research studies have tended to examine homogeneous and highly selected trauma populations. Eighteen of these reports $(67 \% ; 18 / 30)$ were conducted solely on combat veterans and $73 \%(254 / 356)$ of all scanned subjects were male. Furthermore, combat veterans $(58 \%$; 219/377) and survivors of childhood physical and sexual abuse $(27 \%$; 101/377) accounted for $85 \%$ of all subjects recruited to neuroimaging studies. It is vital that future research into the neurobiology of PTSD attempts to incorporate a wider spectrum of trauma.

The triggers causing intrusive thoughts or flashbacks are personal and often idiosyncratic. Research provocation paradigms need to be able to reflect this and if they do not then researchers may be studying different phenomena. The similarity between generalised combat sounds and a self-generated narrative of a fatal motor vehicle accident in which an individual was at fault have little in common and may explain why there was a failure to show amygdalar activation when generalised combat sounds were used rather than personalised trauma scripts. To expect uniform activation of the brain in different trauma populations with varying provoking stimuli is to suggest that all traumas have similar effects and trigger the same symptoms.

The failure of studies to include control or comparison groups (of trauma-exposed subjects without PTSD) leaves the possibility that the observed changes are due to trauma exposure as opposed to PTSD itself. However, there are demonstrated biological changes following trauma exposure that are associated with PTSD and not simply with the trauma exposure per se (Yehuda \& McFarlane, 1995). The neurobiology of PTSD is a progressive state of modification and a cross-sectional perspective cannot answer some of the fundamental questions. Could a pre-existing brain abnormality predispose to PTSD or to exposure to trauma, thereby identifying at-risk individuals? Alternatively, could the trauma exposure rather than PTSD be responsible for the demonstrated structural and functional changes (Sapolsky, 2000)? Only one study has examined neuroimaging changes in individuals with acute PTSD and this suggests that no abnormality existed prior to the development of PTSD (Bonne $e t$ al, 2001). Furthermore, are there identifiable trait effects (defining the underlying disease process) as opposed to state effects (reflecting the symptom severity)? Only the latter have been investigated so far in PTSD.

Other methodological issues would include the standardisation of image acquisition (and analysis) and a consensus on methodologies (e.g. type of trauma population, type of symptom provocation and method of diagnosis). In addition, studies controlling for past and current treatment and the presence or absence of comorbidity are needed to determine the relative contributions. This would allow the pooling of data or a meta-analysis that would compensate for individually small studies.

Neuroimaging studies in PTSD have suggested a number of brain regions meriting further attention. Key regional abnormalities, their replicability and the possible significance of each finding are described in Table 6. Findings to support the proposed right-hemisphere lateralisation of post-trauma symptoms are inconsistent, with no neuroimaging study in PTSD examining the role of dominance (studies have chosen to study dextrals) or gender on this proposed laterality. For example, gender differences have been demonstrated in studies of self-induced dysphoria (Whalen et al, 1998b), with bilateral activation in women and predominantly left-sided activation in men. 
Table 6 Central findings of neuroimaging studies

\begin{tabular}{lc}
\hline Finding & Replicability' \\
\hline Decreased hippocampal volume & $+++^{2}$ \\
Increased amygdala activity & $+++^{2}$ \\
Decreased Broca's area (left inferior cortex) activity & $+^{2}$ \\
Hemispheric lateralisation & $+++^{2}$ \\
Decreased anterior cingulate cortex activation & $++^{2}$ \\
Decreased $N$-acetyl aspartate in medial temporal regions & + \\
Activation in visual cortex & $+^{2}$ \\
\hline
\end{tabular}

I. Replicability was rated as follows: $(+)$ two, $(++)$ three and $(+++)$ four or more studies.

2. Inconsistent findings.

\section{Treatment implications}

Neuroimaging findings suggest that after psychological trauma biological changes are not restricted to dysregulation of neurochemical systems but involve alterations in brain function and structure. The challenge for clinicians is to employ therapies for patients with PTSD that prevent, halt or reverse these changes. Functional brain changes after successful treatment have been demonstrated in other conditions (Schwartz et al, 1996) and preliminary data suggest that the same is true for patients with PTSD (Levin et al, 1999). One possible target is the demonstrated hippocampal damage. The hippocampus may be unique in the brain in its ability to regenerate neurons (Gould et al, 1998), with agents such as phenytoin potentially able to reverse stress-activated hippocampal atrophy (Watanabe et al, 1992). Silver et al (1991) have suggested that anticonvulsants may reduce limbic kindling in PTSD, thereby preventing progression of symptoms, but this has yet to be tested in clinical trials in subjects with acute post-traumatic reactions.

Perhaps one of the least expected early findings is the hypoperfusion of Broca's area when trauma-related memories are provoked. Broca's area is necessary for the labelling of emotions, therefore its deactivation under symptom provocation would explain why patients with PTSD can experience intense emotions without being able to label and understand them. This marries clinically with survivors often describing an inability to put their experience into words - it is, in effect, 'unspeakable'. Therefore, the ability of psychological treatment, especially 'talking therapies', may be compromised during some phases of the disorder. Therapies incorporating exposure have proven efficacy for the treatment of PTSD (van Etten \& Taylor, 1998) and this may be because they can target all sensory modalities and not just their semantic representations. Alternatively, their potency may be explained by the preclinical finding that the reactivation of memory allows its disruption (Nader et al, 2000). Importantly, the reactivation of memory does not require it to be put into communicable language.

The strategies and findings of published neuroimaging studies in PTSD provide a framework for future research, not just in neuroimaging but for clinical trials of historically accepted treatments for trauma survivors. Future neuroimaging studies need to develop protocols to investigate state and trait effects in a range of traumatic events and to study treatment-naïve subjects. Pre- and post-treatment studies also need to be completed to assess the full effectiveness of clinical strategies.

\section{ACKNOWLEDGEMENTS}

I would like to thank Professors David A. Alexander and lan $C$. Reid for their assistance in revising previous drafts of this paper, and Isla Imrie and Louise Winning for locating many of the articles.

\section{REFERENCES}

Adamec, R. (1997) Transmitter systems involved in neural plasticity underlying increased anxiety and defense: implications for understanding anxiety following traumatic stress. Neuroscience and Biobehavioural Reviews, 2I, 755-765.

Benkelfat, C., Bradwejn, J., Meyer, E., et al (1996) Functional neuroanatomy of CCK 4 -induced anxiety in normal healthy volunteers. American Journal of Psychiatry, 152, I180-1184.

Bertolino, A., Nawroz, S., Mattay, V. S., et al (1996) Regionally specific pattern of neurochemical pathology in schizophrenia as assessed by multislice proton magnetic resonance spectroscopic imaging. American Journal of Psychiatry, I53, 1554-1563.
Bonne, O., Brandes, D., Gilboa, A., et al (200I) Longitudinal MRI study of hippocampal volume in trauma survivors with PTSD. American journal of Psychiatry, 158, 1248-1251.

Breiter, H. C., Etcoff, N. L., Whalen, P. J., et al (1996) Response and habituation of the human amygdala during visual processing of facial expression. Neuron, $\mathbf{1 7}$, 875-887.

Bremner, J. D., Randall, P., Scott, J. M., et al (1995) MRI based measurement of hippocampal volume in patients with combat-related post-traumatic stress disorder. American Journal of Psychiatry, 152, 973-981.

_ , _ , Vermetten, E., et al (1997a) Magnetic

resonance imaging-based measurement of hippocampal volume in post-traumatic stress disorder related to childhood physical and sexual abuse: a preliminary report. Biological Psychiatry, 4I, 23-32.

_ , Innis, R. B., Ng, C. K., et al (1997b) Positron emission tomography measurement of cerebral metabolic correlates of yohimbine administration in combat-related posttraumatic stress disorder. Archives of General Psychiatry, 54, 246-254.

_, Staib, L. H., Kaloupek, D., et al (1999a) Neura correlates of exposure to traumatic pictures and sound in Vietnam combat veterans with and without posttraumatic stress disorder: a positron emission tomography study. Biological Psychiatry, 45, 806-816.

_ , Narayan, M., Staib, L. H., et al (1999b) Neural correlates of memories of childhood sexual abuse in women with and without posttraumatic stress disorder. American Journal of Psychiatry, 156, 1787-1795.

_, Innis, R. B., Southwick, S. M., et al (2000)

Decreased benzodiazepine receptor binding in prefrontal cortex in combat-related posttraumatic stress disorder. American Journal of Psychiatry, 157, II20-1126.

Breslau, N., Davis, C. G., Andreski, P., et al (1991) Traumatic events and post-traumatic stress disorder in an urban population of young adults. Archives of General Psychiatry, 48, 216-222.

Cahill, L., Haier, R. J., Fallon, J., et al (1996) Amygdala activity at encoding correlated with longterm free recall of emotional information. Proceedings of the National Academy of Sciences of the United States of America, 93. 8016-8021.

Canive, J. M., Lewine, J. D., Orrison, W.W., et al (1997) M.R.I. reveals gross structural abnormalities in PTSD. Annals of the New York Academy of Science, 82I, 5I2-5I5.

Charney, D. S., Woods, S. W., Goodman, W. K., et al (1987a) Neurobiological mechanisms of panic anxiety: biochemical and behavioural correlates of yohimbineinduced panic attacks. American Journal of Psychiatry, 144, 1030-1036.

_ , _ \& Heninger, G. R. (1987b) Noradrenergic function in generalized anxiety disorder: effects of yohimbine in healthy subjects and patients with generalized anxiety disorder. Psychiatry Research, 27, 173-182.

Davidson, R. J. \& Sutton, S. K. (1995) Affective neuroscience: the emergence of a discipline. Current Opinion in Neurobiology, 5, 217-224.

De Bellis, M. D., Keshavan, N. S., Clark, D. B., et a (1999) Developmental traumatology. Part II. Brain development. Biological Psychiatry, 45, 127|-1284.

Ende, G. R., Laxer, K. D., Knowlton, R. C., et al (1997) Temporal lobe epilepsy: bilateral hippocampal metabolite changes revealed at proton MR spectroscopic imaging. Radiology, 202, 809-817. 
Fischer, H., Wik, G. \& Fredrikson, M. (1996) Functional neuroanatomy of robbery re-experience: affective memories studied with PET. Neuroreport, $\mathbf{7}$ 208I-2086.

Freeman, T.W., Cardwell, D., Karson, C. N., et al (1998) In vivo proton magnetic resonance spectroscopy of the medial temporal lobes of subjects with combat posttraumatic stress disorder. Magnetic Resonance in Medicine, 40, 66-7!.

Friedman, M. J. (1997) Post-traumatic stress disorder Journal of Clinical Psychiatry, 58, 33-36.

Glazer, W. M., Charney, D. S. \& Heninger, G. R. (1987) Noradrenergic function in schizophrenia. Archives of General Psychiatry, 44, 898-904.

\section{Glue, P., Nutt, D. J. \& Coupland, N. J. (1993) Stress} and psychiatric disorder: reconciling social and biological approaches. In Stress: an Integrated Approach (eds S. C. Stanford \& P. Salmon), pp. 53-73. London: Academic Press.

Gould, E., Tanapat, P., McEwen, B. S., et al (1998) Proliferation of granule cell precursors in the dentate gyrus of adult monkeys is diminished by stress.

Proceedings of the National Academy of Sciences of the United States of America, 95, 3168-3171.

Gurvits, T. V., Shenton, M. E., Hokama, H., et al (1996) Magnetic resonance imaging study of hippocampal volume in chronic combat-related posttraumatic stress disorder. Biological Psychiatry, 40 1091-1099.

Helzer, J. E., Robins, L. N. \& McEvoy, L. (1987) PTSD in the general population. New England Journal of Medicine, 317, 1630-1634.

Heninger, G. R., Charney, D. S. \& Price, L. H. (1988) $\alpha 2$-Adrenergic receptor sensitivity in depression: the plasma M.H.P.G., behavioural and cardiovascular responses to yohimbine. Archives of General Psychiatry, 45, $718-726$.

Ikeda, M., Mori, E., Hirono, N., et al (1998)

Amnestic people with Alzheimer's disease who remembered the Kobe earthquake. British Journal of Psychiatry, I72, 425-428.

Kazui, H., Mori, E., Hashimoto, M., et al (2000) Impact of emotion on memory. Controlled study of the influence of emotionally charged material on declarative memory in Alzheimer's disease. British Journal of Psychiatry, I77, 343-347.

Ketter, T. A., Andreason, P. J., George, M. S., et al (1996) Anterior paralimbic mediation of procaineinduced emotional and psychosensory experience. Archives of General Psychiatry, 56, 59-69.

Kosslyn, S. M., Shin, L. M., Thompson, W. L., et a (1996) Neural effects of visualising and perceiving aversive stimuli: a PET investigation. Neuroreport, 7. 1569-1576.

Krystal, J. H., Bennett, A., Bremner, J. D., et al (1995) Toward a cognitive neuroscience of dissociation and altered memory function in post-traumatic stress disorder. In Neurobiological and Clinical Consequences of Stress: from Normal Adaptation to PTSD (eds M. J. Friedman, D. S. Charney \& A. Y. Deutch), pp. 234-269. New York: Raven Press.

Levin, P., Lazrove, S. \& van der Kolk, B. A. (1999) What psychological testing and neuroimaging tell us about the treatment of posttraumatic stress disorder by eye movement desensitization and reprocessing. Journa of Anxiety Disorders, 13, 159-172.

Liberzon, I., Taylor, S. F., Fig, L. M., et al (1996/97) Alteration of corticothalamic perfusion ratios during a PTSD flashback. Depression and Anxiety, 4, 146-150.

\section{CLINICAL IMPLICATIONS}

- More work is needed to identify treatments that reverse the demonstrated functional and structural regional brain changes.

- The effectiveness of psychological treatments, especially 'talking therapies', may be compromised by underactivity of Broca's area when individuals are accessing traumatic material.

- Possible right-hemispheric lateralisation may explain the 'timeless' quality of traumatic memories.

\section{LIMITATIONS}

- The majority of studies are restricted to highly selected and homogeneous samples.

Many of the studies lacked a control or comparison group and therefore did not exclude the possibility that observed changes are the result of exposure to the trauma itself rather than to post-traumatic stress disorder.

- Unpublished studies are not discussed.

ALASTAIR M. HULL, MRCPsych, Department of Mental Health and Aberdeen Centre for Trauma Research, University of Aberdeen

Correspondence: Dr Alastair Hull, Lecturer, Aberdeen Centre for Trauma Research, Bennachie, Roya Cornhill Hospital, Aberdeen AB25 2ZH,UK. E-mail: alhul@aol.com

(First received 18 October 200I, final revision 12 March 2002, accepted 19 March 2002)

_, , , Amdur, R. L., et al (1999) Brain activation in PTSD in response to trauma-related stimuli. Biological Psychiatry, 45, 817-826.

Lucey, J.V., Costa, D. C., Adshead, G., et al (1997) Brain blood flow in anxiety disorders: OCD, panic disorder with agoraphobia, and post-traumatic stress disorder on $99 \mathrm{mTCHMPAO}$ single photon emission tomography (SPET). British Journal of Psychiatry, I7I, 346-350.

McEwen, B. S. (1997) Possible mechanisms for atrophy of the human hippocampus. Molecular Psychiatry, $\mathbf{2}$ $255-262$

MacKay, S., Ezekiel, F., Selafani, V. D., et al (1996) Combining MRI segmentation and HMR spectroscopic imaging in the study of Alzheimer's disease, subcortical ischaemic vascular dementia and elderly controls. Radiology, 198, 537-545.

Markowitsch, H. J., Kessler, J., Van Der Ven, C., et a (1998) Psychic trauma causing grossly reduced brain metabolism and cognitive deterioration Neuropsychologia, 36, 77-82.

Mori, E., Ikeda, M., Hirono, N., et al (1999) Amygdalar volume and emotional memory in Alzheimer's disease. American Journal of Psychiatry I56, 216-222

Morris, J. S., Frith, C. D., Perrett, D., et al (1996) A differential response in the human amygdala to fearful and happy facial expressions. Nature, 38, 812-8I5.
Myslobodsky, M. S., Glicksohn, J., Singer, J., et al (1995) Changes of brain anatomy in patients with posttraumatic stress disorder: a pilot magnetic resonance imaging study. Psychiatry Research, 58 259-264.

Nader, K., Schage, G. \& LeDoux, J. E. (2000) Fea memories require protein synthesis in the amygdala for reconsolidation after retrieval. Nature, 406, 722-726.

Peters, J., van Kammen, D. P., van Kammen, W. B. et al (1990) Sleep disturbance and computerised axial tomographic scan findings in former prisoners of war Comprehensive Psychiatry, 31, 535-539.

Rasmussen, S. A., Goodman, W. K., Woods, S.W., et a (1987) Effects of yohimbine in obsessive-compulsive disorder. Psychopharmacology, 93, 308-313.

Rauch, S. L., Savage, C. R., Alpert, N. M., et al (1995) A positron emission tomographic study of simple phobic symptom provocation. Archives of General Psychiatry, 52. 20-28.

_, van Der Kolk, B. A., Fisher, R. E., et al (1996) A symptom provocation study of post-traumatic stress disorder using positron emission tomography and script driven imagery. Archives of General Psychiatry, 53. 380-387.

_, Savage, C. R., Alpert, N. M., et al (1997) The functional neuroanatomy of anxiety: a study of three disorders using positron emission tomography and symptom provocation. Biological Psychiatry, 42, 446-452. 
_ , Whalen, P. J., Shin, L. M., et al (2000) Exaggerated amygdala response to masked facial stimuli in posttraumatic stress disorder: a functional MRI study. Biological Psychiatry, 47, 769-776.

Sapolsky, R. M. (1992) Stress, the Aging Brain and the Mechanisms of Neuron Death. Cambridge, MA: MIT Press.

- (2000) Glucocorticoids and hippocampal atrophy in neuropsychiatric disorders. Archives of General Psychiatry, 57, 925-935.

Schacter, D. L., Alpert, N. M., Savage, C. R., et a (1996) Conscious recollection and the hippocampa formation: evidence from positron emission tomography. Proceedings of the National Academy of Sciences of the United States of America, 93, 321-325.

Schuff, N., Marmar, C. R., Weiss, D. S., et al (1997) Reduced hippocampal volume and $\mathrm{N}$-acetyl aspartate in post-traumatic stress disorder. Annals of the New York Academy of Sciences, 82I, 516-520.

Schwartz, J. M., Stoessel, P. W., Baxter, L. R., et al (1996) Systematic changes in cerebral glucose metabolic rate after successful behaviour modification of obsessive-compulsive disorder. Archives of General Psychiatry, 53, 109-113.

Semple, W. E., Goyer, P., McCormick, R., et al (1993) Preliminary report: brain blood flow using P.E.T. in patients with post-traumatic stress disorder and substance-abuse histories. Biological Psychiatry, 34 II5-II8.

_ , _ , _ , et al (1996) Attention and regional cerebra blood flow in posttraumatic stress disorder patients with substance abuse histories. Psychiatry Research, 67, 17-28.

_ , _ _ _ , et al (2000) Higher brain blood flow at amygdala and lower frontal cortex blood flow in PTSD patients with comorbid cocaine and alcohol abuse compared with normals. Psychiatry, 63, 65-74.

Shapiro, F. (1996) Eye movement desensitization and reprocessing (EMDR): evaluation of controlled PTSD research. Journal of Behaviour Therapy and Experimental Psychiatry, 27, 209-218.

Shin, L. M., Kosslyn, S. M., McNally, R. J., et al (1997a) Visual imagery and perception in posttraumatic stress disorder. A positron emission tomographic investigation. Archives of General Psychiatry, 54, 233-24l.

_, McNally, R. J., Kosslyn, S. M., et al (1997b) A positron emission tomographic study of symptom provocation in PTSD. Annals of the New York Academy of Sciences, 82I, 52I-523.

_, _ _ _, et al (1999) Regional cerebral blood flow during script-driven imagery in childhood sexual abuserelated PTSD: a PET investigation. American Journal of Psychiatry, I56, 575-584.

Silver, J. M., Shin, C. \& McNamara, J. O. (1991)

Antiepileptogenic effects of conventional anticonvulsants in the Kindling Model of Epilepsy. Annals of Neurology, 29 356-363.

Silverman, J. J., Hart, R. P., Stockman, S. J., et al (1989) Eighteen-month follow-up of neuropsychiatric effects of pentaborane intoxication. Journal of Traumatic Stress, 2, 463-476.

Southwick, S. M., Krystal, J. H., Morgan, C. A., et a (1993) Abnormal noradrenergic function in posttraumatic stress disorder. Archives of General Psychiatry, 50, 266-274.
Stein, M. B., Koverola, C., Hanna, C., et al (1997) Hippocampal volume in women victimised by childhood sexual abuse. Psychological Medicine, 27, 95I-959.

van Etten, M. \& Taylor, S. (1998) Comparative efficacy of treatments for post-traumatic stress disorder: a meta-analysis. Clinical Psychology and Psychotherapy, 5, 126-144.

Watanabe, Y. E., Gould, H., Cameron, D., et al (1992) Phenytoin prevents stress and corticosterone induced atrophy of CA3 pyramidal neurons. Hippocampus, $\mathbf{2}$ $431-436$.

Whalen, P. J., Bush, G., McNally, R. J., et al (1998a) The emotional counting stroop paradigm: a MRI probe of the anterior cingulate affective division. Biological Psychiatry, 4, 1219-1228.

_ , Rauch, S. L., Etcoff, N. L., et al (1998b) Masked presentations of emotional facial expressions modulate amygdala activity without explicit knowledge. Journal of Neurosciences, $18,4 \mid 1-418$.

Yehuda, R. \& McFarlane, A. C. (1995) Conflict between current knowledge about posttraumatic stress disorder and its original conceptual basis. American Journal of Psychiatry, 152, 1705-1713.

_ , Southwick, S. M., Nussbaum, E., et al (1991) Low urinary cortisol in PTSD. Journal of Nervous and Mental Disease, I78, 366-378.

_, _, Krystal, J. H., et al (1993) Enhanced suppression of cortisol following dexamethasone administration in post-traumatic stress disorder. American Journal of Psychiatry, 150, 83-86.

Zubieta, J-K., Chinitz, J. A., Lombardi, U., et al (1999) Medial frontal cortex involvement in PTSD symptoms: a SPECT study. Journal of Psychiatric Research, 33, 259-264. 